\title{
New Paradigm of Marine Geopark Concept and Information System Based of Webserver at Bangka Belitung Islands, Indonesia
}

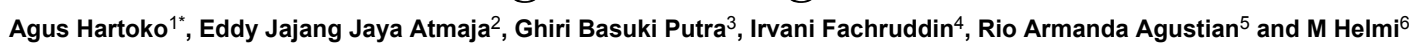 \\ ${ }^{1}$ Department of Fisheries, Diponegoro University, Indonesia \\ ${ }^{2}$ Department of Agribisnis, University of Bangka Belitung, Indonesia \\ ${ }^{3}$ Department of Electronic Engineering, University of Bangka Belitung, Indonesia \\ ${ }^{4}$ Department of Mining, University of Bangka Belitung, Indonesia \\ ${ }^{5}$ University of Bangka Belitung, Indonesia \\ ${ }^{6}$ Department of Marine Science, Diponegoro University, Indonesia
}

"Corresponding author: Agus Hartoko, Department of Fisheries, Faculty of Fisheries and Marine Science University of Diponegoro, Indonesia, Tel: +62-24-8452560; Email: agushartoko@gmail.com

Received Date: October 25, 2018; Accepted Date: November 15, 2018; Published Date: November 23, 2018

Copyright: (c) 2018 Hartoko A, et al. This is an open-access article distributed under the terms of the Creative Commons Attribution License, which permits unrestricted use, distribution, and reproduction in any medium, provided the original author and source are credited.

\begin{abstract}
Based on UNESCO, Geopark is a defined area with a series of specific geological features, variety of endemic flora and fauna aimed for local and regional educational and economic development. Several areas in Indonesia had been designated as geopark and one of them is at Bangka Belitung Province by Indonesian Geopark Authority in 2017. Potential development of Bangka Belitung Geopark based on the uniqueness of its million years old granite rocks, but mostly were located and land-based and none referred to coastal and islands oriented. This paper will focused to explore and develop the uniqueness of coastal areas and islands into a new concept of Marine Geopark paradigm as a cluster of geological uniqueness of granite rocks, its endemic coastal flora and fauna, maritime anthropology as well as many type of sunken war-ship and merchant treasures. Aims of the study were to explore and develop as pioneer step of new paradigm and concept of Marine Geopark for educational and tourism purposes especially Geo Tourism and its management. The study reveals the uniqueness of underwater coral uplift onto coastal land at north Bangka and islands granite rock types on Mindanau, Kelapan, Begadung islands, many endemic orchids such as Gammato phylum speciosum, Dillenia. sp, Hoya. spp, herbal vegetation's in some marginal sandy coastal areas, endemic fauna of Tarsius bancanus, Rasbora bankanensis, old ethnic house for homestay, the Hinduism maritime anthropological sites of Kota Kapur, many sites of sunken merchant and war-ship at Mindanau islands and the specific of the Gaspar strait oceanographic phenomenon. Ancient tribes of Suku Lum, Bubungtujuh at north Bangka and Suku Sekak of Belitung. The designated site for marine geopark then was protected legally with a community based village law. Information system based Webserver will be design and developed to speed and strengthen for regional and global access of the Bangka Belitung marine geopark information and management using PhP and MySQL and the information system that can be access via Internet in all over the world by people using the computer and smartphone.
\end{abstract}

Keywords: Marine-Geopark; Information System; Webserver; Bangka-Belitun

\section{Introduction}

Indonesia as an archipelagic country with about 17,000 islands defined as the largest archipelagic country. Coastline with about 81,000 $\mathrm{km}$ with beautiful beaches. Present day nine National Geopark have been designated in Indonesia and later on has been International Global Network (Global Geopark Network) administrated by UNESCO. Indonesia with thousands of its islands should then develop the concept of Marine Geopark with more focus on discovering of many characters of coastal and small islands with its endemic marine and coastal ecosystem, granite rock, maritime anthropology of ethnic, ancien tribes, flora fauna other than of its beauty. Supported with the presence of many sunken ships and warship aircraft with thousands pieces of Chinese and European ceramics. The need for new concept of Marine Geopark to be developed in Indonesia is inavitable. In economic point of view means as a new marine ecotourism destinations with its many multiplier effects. As well as a pioneering step in developing the concept of Marine Geopark to be in the Global Network as the largest archipelagic state in the world. The Province of Bangka Belitung Island is a province with 700 small islands which of them inhabited and uninhabited [1], had declared developing Geopark concept to be the first and one in Indonesia [2]. Marine Geopark would be defined as the other concept of the land geopark with more strength on coastal, the sea, coastal geology on small islands. As in the concept of Integrated Coastal Zone Management that series of coastal thematic spatial data base such as basic map, coastal land use, ownership and suitability, coastal infrastructure, ecosystem and natural resources, potential risk and hazards, zonation, strategic planning and action plan should be prepared and used [3]. The major problem of small islands remoteness, information database, new concept of marine geopark, shifting of mind, local community awareness, active participation and income should be set in a such integrated information system that could fill in the gap between the resources to potential tourist so that can be easy and widely accessed.

Aim of the study is to explore the coastal and marine natural resources, socio-cultural and economic potentials for sustainable 
Citation: Hartoko A, Atmaja EJJ, Putra GB, Fachruddin I, Agustian RA et al. (2018) New Paradigm of Marine Geopark Concept and Information System Based of Webserver at Bangka Belitung Islands, Indonesia. J Coast Zone Manag 21: 464. doi: $10.4172 / 2473-3350.1000464$

Page 2 of 7

ecotourism by means of an integrated information system based on optimum use of multi-media in the internet system of webserver system using $\mathrm{PhP}$ and MySQL. All kind of Marine Geopark data already collected, would be stored and managed using the information system based on webserver that can be accessed by Internet. As the fundamental concept of information system is to make it easy the management and development the Marine Geopark in the future. According to O'Brien et al. [4] information system can be any organized combination of people, hardware, software, communication networks, data resources, and policies or procedures that had been stores, retrieves, transforms and disseminate information in an organization. Information System [5] as a compilation of component and its subsystem of information and computer system including the interactive input-process-output for an open community use. Webserver as the supporting unit of the information system is the increasing dependence on the internet services emphasizes importance of stable underlying web server architecture [6]. Multithreaded architecture is a natural way of programming a server and is the most common approach for implementing web servers [7].

\section{Methodology}

Field observation and exploration to discover new marine and coastal characters of each geosite clusters, laboratory examinations, secondary data and reference book analysis, in depth communications and interview with local community and web server development plan as in Figure 1. Evaluation method, to develop a scheduled evaluation process by an independent panels representing all stakeholder parties. Product and Segment diversity, tourism consist of main three component are 1 . tourist origin country as the supplier country, 2. tourist destination as the acceptance part, 3. transit routes from origin country to tourist destination [8]. Furthermore clarify into three main element as 1. tourist, 2. geographical (travel generator, transit route, and tourist destination), 3. tourism industry [9].

$\mathrm{PhP}$ (Hypertext Preprocessor). PhP is a code script inserted into a HTML (Hyper Text Markup Language) system, for dynamic web situs development and CSS (Cascading Style Sheet). Application developed by $\mathrm{PhP}$ would resulted on the web browser, with all process running by the server. MySQL, is Relation Database Management System (RDBMS) an open resources software under license of GPL (General Public License) but limited not for a commercial business using MySQL. Which is originally of former database concept of SQL (Structure Query Language). Web Server, is a software in the server function for to accept the request as a home page in the web through HTTP (Hyper Text Transfer Protocol) or HTTPS of client as widely known as browser, then responding the request as web page in the form of HTML document [5,10-12].

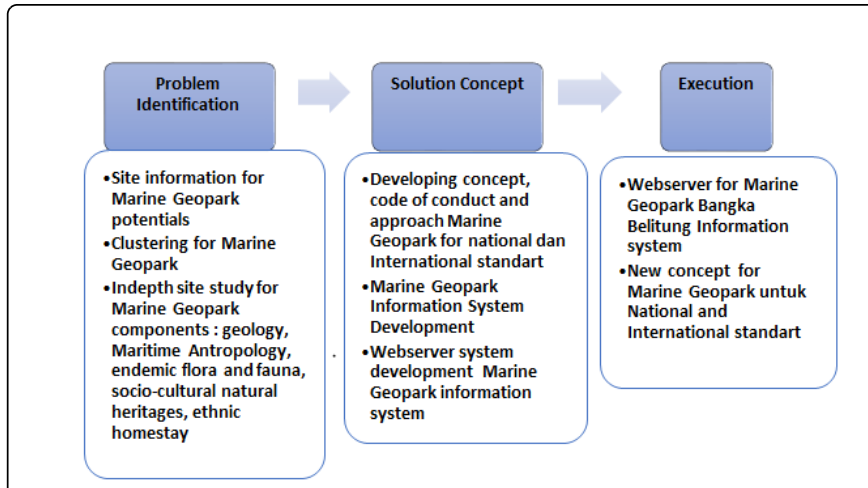

Figure 1: Developing Marine Geopark Information System of Bangka Belitung.

\section{Result and Discussions}

Definition of Geopark or Geological Park is a defined area with its geological, archaeology, morphological an ecosystem characters as the natural and cultural heritage for educational or economic development with active participation of local community. According to GGN UNESCO 2004, aims of Geopark are to manage the natural heritage, respect, conserve and develop to the optimum benefit for universal use and local community. Marine as defined as all part of the sea from surface to the bottom, its flora and fauna. Geo tourism as a new term in tourism use in mid-1990 by Tom Hose, geologist of Buckinghamshire Chilterns University, England in his paper "Geo tourism, or can tourists become casual rock hounds: Geology on your doorstep", book of Geological Society 1996 edition. After introduction by Tom Hose and other European geologist later become a special kind of tourism with more emphasis on natural resources, geology, earth history, natural phenomena and thus need the enrichment than a "back-pack tourism as booming in early 1980 [13]. Impacts in Principal of Geo tourism. There were 13 principal items as listed in the Geo tourism charter of National Geographic Society are 1. Site Integrity. High geographical character reflecting the natural - cultural heritage and local wisdom to conserve, develop for economic differentiation and benefit, 2. International Code : code of conduct on Global Ecotourism Organization and Cultural Tourism Rights by International Council of Monuments ICOMOS/International Council on Monuments and Sites, 3. Market Selectivity, encourage in a segmented tourism to respect and distribution of information of local assets, 4. Market diversity, to encourage of local culinary and accommodation facilities for wider spectrum of demographic diversity for wide geo tourism market share, to strength the short and long-term economic persistence, 5. Tourist satisfaction, to make sure of tourist satisfaction for interpersonal good story about the new destination for a continued tourist visits demand, 6. Active community participation, that is through the development of a community based encouraging of small economic enterprises, traditional markets including historical sites and its guide, art and cultural shows of local community, 7. Benefit for local community, by means of encouraging of micro and middle economic enterprises, 8. Encourage of local business practices with orientation on conservation on natural heritage and local wisdom on a controlled tourism activities, 9. Land use, anticipation and adaptation to the possible future tourism development and avoid of land degradation, 10. Natural resources conservation measures and 
Citation: Hartoko A, Atmaja EJJ, Putra GB, Fachruddin I, Agustian RA et al. (2018) New Paradigm of Marine Geopark Concept and Information System Based of Webserver at Bangka Belitung Islands, Indonesia. J Coast Zone Manag 21: 464. doi: $10.4172 / 2473-3350.1000464$

Page 3 of 7

practices on the tourist development for sustainable natural and community benefit with good code of conduct for the waste treatments, 11. Continuous evaluation and planning with respect to the sustainability of natural resources based on the local geo tourism characters, 12. Good management practices by means of controlling the number of tourist to the capacity of the natural resources, 13 . Encouragement for local community in promoting local heritage and interactive interpretation of host and tourist [14-17]. It has been hundred years long period, since the Dutch colonization the two main resources of Bangka Belitung islands known as Muntok White Piper and tin had been heavily exploited and become the main economy [18]. The new concept of Marine Geopark, scientifically need to be studied and developed to comply for national and international geopark standard. Ultimately, with the setting as new concept of
Bangka Belitung Marine Geopark should be a new specific education tourism destination and brings a new of economic value. This would be a new adaptation of the islands economic recovery of the long last tin post mining era.

Map of the overall Bangka Belitung Marine Geopark development plan as in Figure 2. The main concept of the study was development of marine geopark based on the integration of each geosite development plan that should have its different and characters of its natural granite rock types, endemic flora (many types of herbal flora), coastal and marine fauna, ancient tribe, maritime anthropology or socio-cultural heritages (such as old-spell or the 'Mantra', songs, Dam-bus music instruments, the 'Kedidi' dances), old wooden houses.

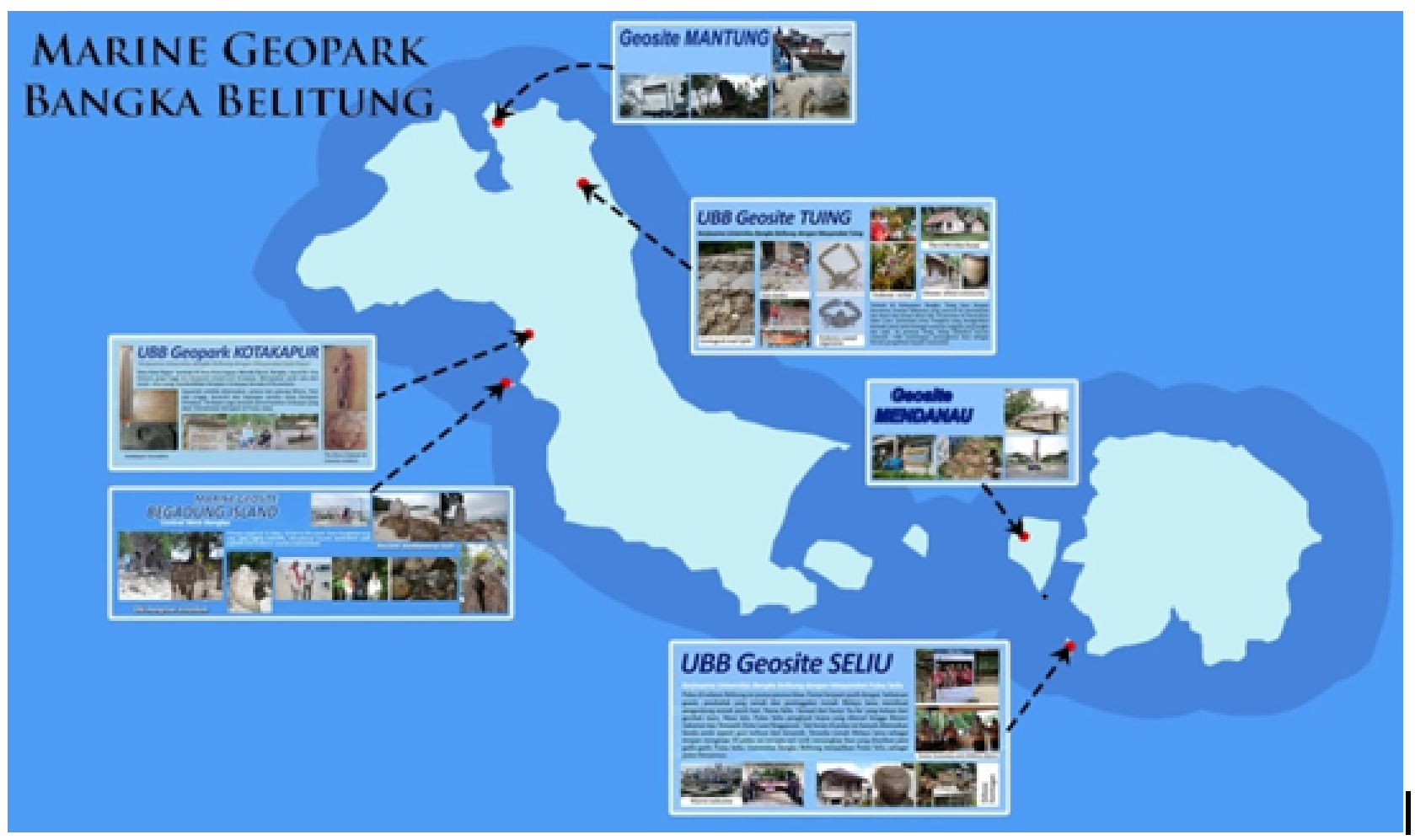

Figure 2: Map of Bangka Belitung Marine Geopark Development Plan.

Tuning costal area is a village at Belinyu district of Bangka regency of the main island, about $70 \mathrm{~km}$ from Sun gailiat city (Figure 3). Marine geosite of Tuning coastal village were characterized with the presence and the only can be found of the entire island the evidence of geological coral uplift process. Where the underwater coral reef ecosystem, complete with its abundance animal associated such as bevel via, gastropods and foraminifer community in the biotic carbon sediments undergone of heat and solidify was uplifted on to the above high tide coastal area. This specific coastal area would be very important field example for an educational tourism with its completely recorded. The abundance species of endemic flora such as Hoya. sp as widely recognized as the specific of Bangka flora, many species of endemic orchids in a marginal sandy coastal area. Beside the existence of endemic squid (Loligo. sp) spawning site, sandy crab (Crustacean), the Lump (animism) ancient tribe, old Chinese community, old wooden houses and old Chinese ceramics make it as perfect marine geosite. 
Citation: Hartoko A, Atmaja EJJ, Putra GB, Fachruddin I, Agustian RA et al. (2018) New Paradigm of Marine Geopark Concept and Information System Based of Webserver at Bangka Belitung Islands, Indonesia. J Coast Zone Manag 21: 464. doi: $10.4172 / 2473-3350.1000464$
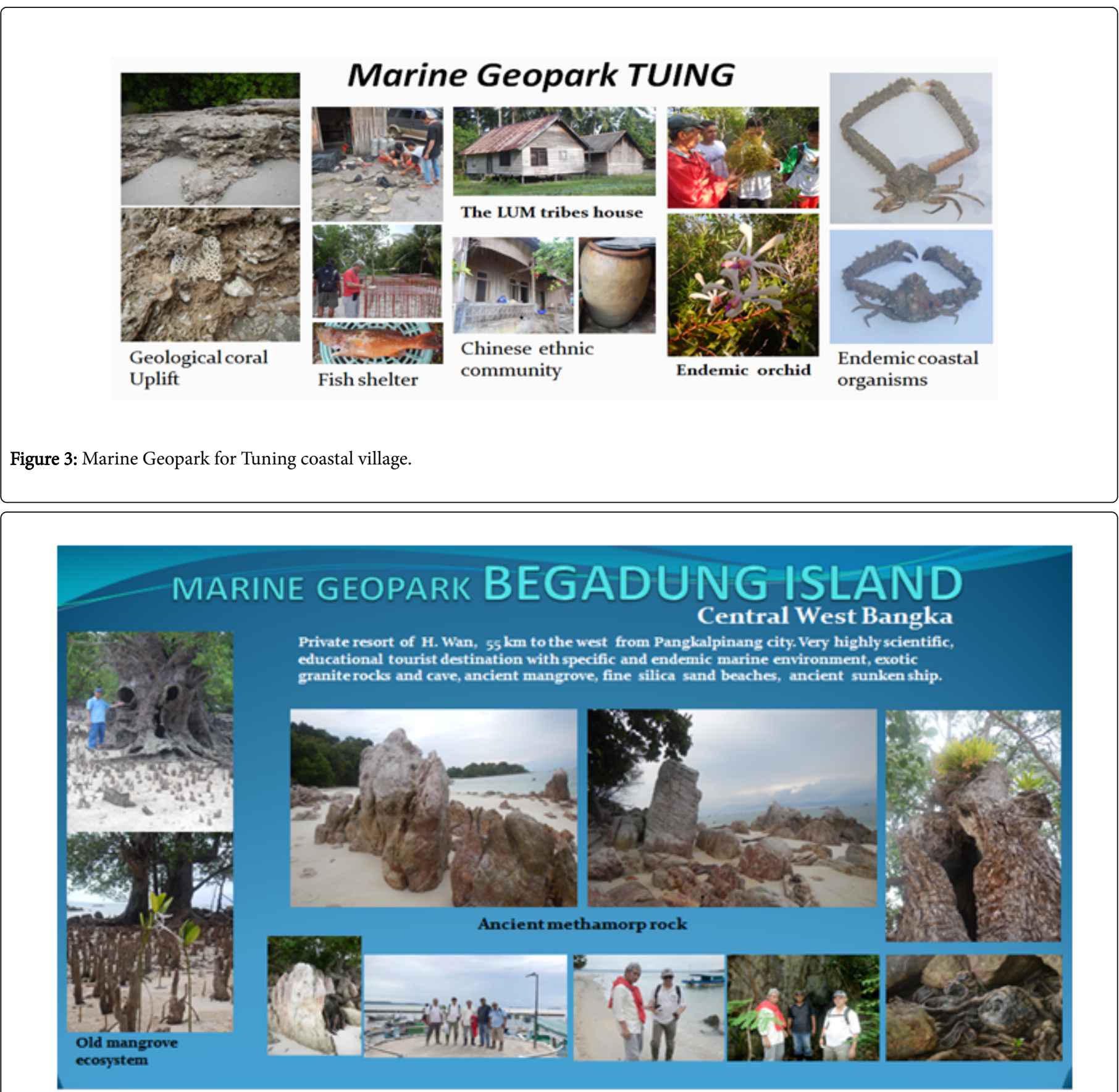

Figure 4: Marine Geopark of Begadung islands - west coast of Central Bangka.

Marine geopark of Begadung islands (Figure 4), central west coast of Bangka was characterized with unique type of Ancient vertical layering reddish sedimentary-low grade meomorphic rock types. Sedimentary rocks caves going to below sea water level, make it very challenging to explore. The existence of very old natural and undisturbed Bruguier $\mathrm{sp}$ mangrove community, with its specific adaptive root system to the granite rock trajectory at the coastal area. The presence of European and Japanese warship underwater wreck. 
Citation: Hartoko A, Atmaja EJJ, Putra GB, Fachruddin I, Agustian RA et al. (2018) New Paradigm of Marine Geopark Concept and Information System Based of Webserver at Bangka Belitung Islands, Indonesia. J Coast Zone Manag 21: 464. doi: $10.4172 / 2473-3350.1000464$

Page 5 of 7

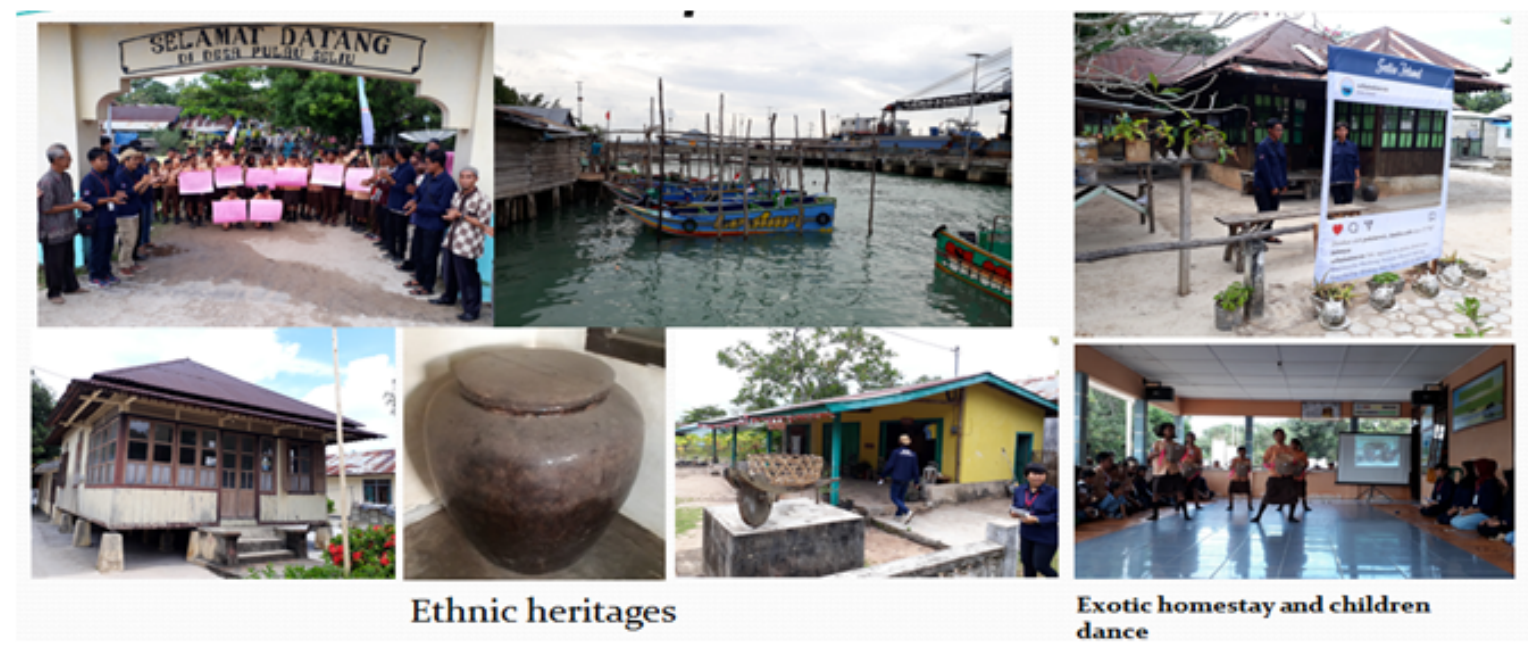

Figure 5: Marine geopark cluster for Seliu Island - Bangka Belitung.

Marine geopark for Seliu island had found a very strong kind of islands life style, boats, fisherman houses and most specific is the presence of many type of old wooden stage-houses.

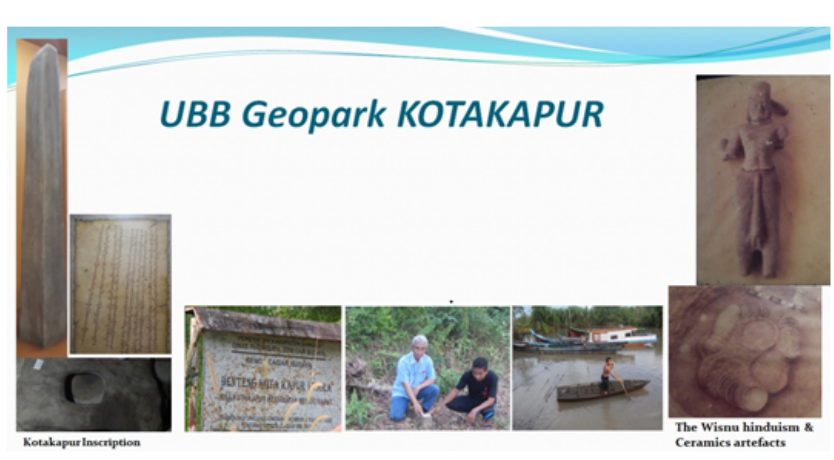

Figure 6: Marine geopark cluster of 'Kota Kapur' Maritime Anthropology - Bangka.

'Kota-Kapur' site is known as part of the Sriwijaya kingdom with its main capital at nowadays known as Palembang, south Sumatera province and later on the site was designated and to be developed as maritime anthropological marine geopark (Figures 5 and 6). At this site were found some maritime art fact such as old wooden boat, stone jetty. The most valuable of all is inscription-stone of 'Kota-Kapur' with a Sanskrit Hinduism character, stone statue of the Whisnu and old Chinese ceramics, swords, spears and others.

In general, the geomorphological feature of Bangka and Belitung island is a gently slope surface. The geological description of the tinislands Bangka-Billiton [19] and Pre-tertiary formations. Crystalline schist's were supposed to be the oldest formation, older than the Triassic flysch [20]. The oldest formation of Bangka is represented by limestone's, proving their perm-carboniferous age. Followed with phyletic shale's and quartzite's refer to the upper-Triassic flysh formation and intercalations of radiolarian-bearing cherts in the formation. The radiolarian bearing cherts were cut by veinlet's of quartz with some arsenopyrite and chalcopyrite. Most of granites are post-Triassic, presumably Jurassic in age. Microscopically biotite granite in most cases consisting of quartz, orthoclase, oligoclase and subordinate amount of zircon, apatite and orthite. The granite along the coast sometimes contains dark streaks of biotite alternating with leucocratic bands. This flow structure or a relic of the meta somatically replaced sediments. Black tourmaline schorl and fluorite are sometimes very abundant in the granite. In the Holocene, after a long period of denudation and pen planation, during which secondary ages were formed, the relative rise of the sea has caused the transgression of the sea over the part of the Sunda land. Regional physiography of Bangka - Belitung island physio graphically is the biggest island in the Sunda-Shelf, and as the Sunda Pen plain [22]. Its geological order is part of Tin Island sat Sunda land Craton of Eurasia plate [21] and part of the Southeast Asia tin-belt [22]. The Sunda plate to form the relatively stable Sunda land, as the amalgamated of some terrane Perm [23]. Granite rocks of Bangka Belitung of Tries Jura age as composite of granite, granodorit, Adam alit, diorite and diorite quartz with a plit and pegmatite breaks $[24,25]$. Texture of granite with variations where some sesars tin-granite as the youngest to form monadnocks. While older granite observed at low plain [26]. Intrusion of granite were found of largest granite at Klabat, Plangas, Menumbing, Mangkol, Tempilang and Toboali [27]. In general that granite texcture of Belitung are almost the same of Bangka, but with some variation of its composites [28]. Batholit distributed as in Tanjungpandan, Adamelit Baginda, Granodiorit Burungmandi and Batubesi quartz. Based on geochemical and granite isotope of the tin island age of 220 million years, example of Belinyu about $(251 \pm 10)$ million years and Penangas of $(252 \pm 8)$ million or Late of Trias [22,24]. Belitung granite of TriasKapur of (245 \pm 115$)$ million of age [30] but about 193-2251 million years of age according [29]. Geomorphological type of geosite the Menumbing granite rocks of West Bangka island is a part of Batolith Granit hilly landscape. The adjacent of the Bukit Kukus with predominantly steep slope hill. Lithology of Bukit Kukus rocks geosite with light greyish, faneritic texture, holo crystalline, relatively equi granular, massive structure with predominant mineral of plagioclase, quarts and small portion of K-Feldspar, muscovite and biotit. Based on the above characters later on as mega scopicaly grouped into the 'granitic' solid rock. According to Mangga AS, et al. [24] was grouped 
Citation: Hartoko A, Atmaja EJJ, Putra GB, Fachruddin I, Agustian RA et al. (2018) New Paradigm of Marine Geopark Concept and Information System Based of Webserver at Bangka Belitung Islands, Indonesia. J Coast Zone Manag 21: 464. doi: $10.4172 / 2473-3350.1000464$

Page 6 of 7

as Klabat granites of Trias - Jura age [30]. Geological structure of Bukit Kukus as sheeting joints to form a solid block of rocks with a certain dimensions. The main sheeting joint was caused by previous tectonic process and some by pressure release. The formation of sheeting joints are compressed, tensile and scour sheets by pressure release of the rocks, characterized with capilar of quarts $0.5 \mathrm{~cm}$ thickness. Geomorphology of Mendanau island in general is relatively flat terrain composed by sediment rocks. Lithology of its part known as Suak Gual where sediment rock was found. Sediment rock was formed of sandy rocks with insertion of silt and clay rock. Characterized with yellowish grey and reddish color, medium and fine grain size, fine and moderately sorted, laminated structure with main quarts mineral composition. Sheeted with relatively close spat ion and dominant quarts capilar of less than $1 \mathrm{~cm}$ thickness. Slate rocks or clay rocks with brownish grey and red, smooth surface. Based on the above characters compatible into sediment rock of Kelapakampit formation with Permcarbon age sediment in a coastal and sea environment [28]. Geological structure of Suak Gual at Mindanau island is mainly sheeting joints with insertion of mineral secunfer (capilar). Sheeting joints is in block formation systematically, caused by tectonic process. Layer slope of rocks was found in dimension of $\mathrm{N} 250 \mathrm{oE} / 16 \mathrm{o}$ and N15oE/20o. Which is classified as gentle slope and topographically according to the slope of sedimentary rocks. Tectonic activity since Perm carbon with the formation of flysch sediment in 'Kelapakampit' formation, followed by collision process to became 'Siantu' formation. Magmatic activity during Tries period to form Tanjungpandan granite. Beginning of Jura followed by magmatic activity to the'Adamalit Baginda' formation and ended at late carbon with the insertion of granodiorit rocks. Since late carbon quarter, erosion process and sedimentation to form a sandy carbon and alluvium [28].

Marine ecotourism. Based on the definition of geopark, is a specific need/driven tourism on natural resources, geological characters or earth history and thus need to be enriched with those natural geoinformation's to drive motivation of tourist. As compared with cultural, culinary or historical and heritages tourist destinations. According to Mohamed B, et al. [8] there were two main model of tourist types, that is cognitive-normative model and interactive model. These classify tourist types based on their intention for a unique, remote, unpopular as well as tourist type to specific geosite or geo tourism and the way they manage the trip, individual, group or tour-package by agent. Drifter tourist and explorer to specific destinations, different with popular tourist or mass tourist. The cognitive-normative model classify into alocentric- tourist and mid centric tourist rather than psycho centric ones. The interaction model classify into drifter tourist, explorer tourist, mass tourist and regular mass tourist. Flow of tourist [8] as a form of spatial interaction from supply site and destination. The supply site as the beginning of a tourist activity, whereas in marketing aspect as the supplier of the tourist demand. The tourist destination have some icon or characters that the supplier do not have. While alocentric tourist as demanding activity tourist type, tend to do any kind of exploring activity especially the new and challenging ones $[15,31,32]$.

The new developed marine geopark at Bangka Belitung islands such as at Tuning coastal village, Begadung island, Kota Kapur and Mindanao island and some others would imply to this alocentric tourism as the target of marketing and also developing the information system for marine geopark. The development of new concept on marine geopark at Bangka Belitung islands in the study would drive the emergence of geosite novelties integration such as geology, morphology, socio-cultural heritages in one information system. Some new perspective and innovations had been developed where old buildings of fishermen wooden houses had been designated as home stays, heritage seafood culinary added with scientific touch such as collagen and chondroitin rich seafood good for health, and many other coastal village products. These had a direct impact to the increasing income and active participative and involvement of local people. New specific coastal community events had been developed socio-culturally such as alms sea celebration. Overnight light fishing and seafood explore with many type of local wooden boat, mangrove lagoon ecogreen, turtle and squid conservation round trip. Development of local based new product such as natural mangrove pigment for 'batiks', fresh drink from mangrove fruits, natural mangrove honey-bee culture in an eco-developed mangrove ecosystems. In turn, this development will rise new sectors in geo tourism activity such as local hand-made handicraft, travel agents and specific tour guides opportunities and prevent to a decline of tourism phase. As comparable example of the Langkawi geopark case try to rehabilitate the decline after undergone life cycle [33-35].

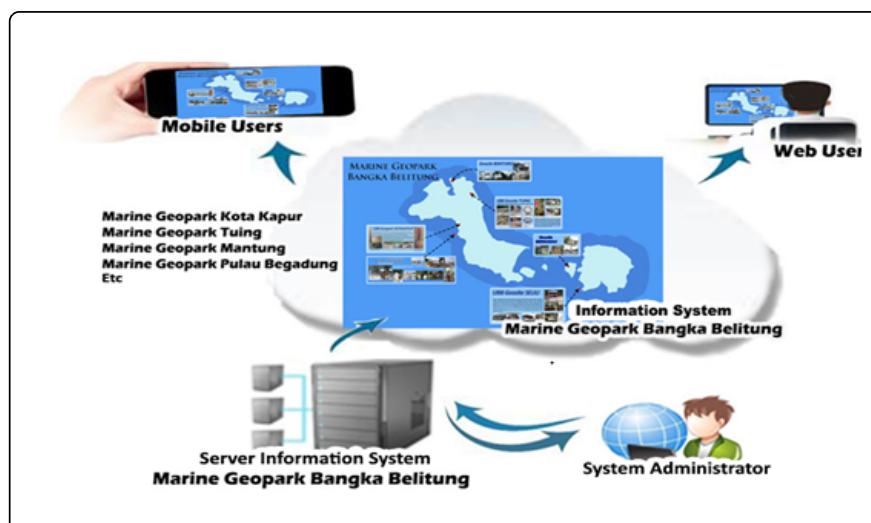

Figure 7: Information System for Marine Geopark at Bangka Belitung Islands.

As in Figure 7, the developed webserver based Information System for the new concept of Marine Geopark at Bangka Belitung islands. The kind of information system developed specifically the use of internet and accessed on smartphone with consideration on limited islands condition and telecommunication facilities, even the worst is the very limited of power supply. The information system of Marine Geopark at Bangka Belitung based on PHP and MySQL with focus to promote the specific information on each marine geosite, mainly photograph and short video with support of general information such as transportation and local accommodations. Information System make the access of Marine Geopark data by many people at all over the world will be easily using the Internet.

\section{Summary}

The new concept of marine geopark as developed not just of coastal geological or geomorphological character but also addition information of the rare and the least known of Bangka Belitung islands specially and many other small islands of Indonesia. The integration with time anthropological and socio-cultural heritages, coastal and marine resources, other local food, product, homestay. Based on some year's experiences, the local community awareness, socialization for active participation thus the need to educate and train local community was inevitable. Such as to be tourist guide, give other perspective, new knowledge, with key word "the usual for local is the 
Citation: Hartoko A, Atmaja EJJ, Putra GB, Fachruddin I, Agustian RA et al. (2018) New Paradigm of Marine Geopark Concept and Information System Based of Webserver at Bangka Belitung Islands, Indonesia. J Coast Zone Manag 21: 464. doi: $10.4172 / 2473-3350.1000464$

Page 7 of 7

unusual/ extraordinary fo tourist". Developed some new geosite, events in a year, product, how to promote, manage the local resources for sustainable use. Some geosite had been successfully developed are Tuning coastal village, Begadung Island, Toboali South Bangka regency mangrove tracking and local products, the Hinduism 'Kota Kapur' maritime anthropology site of Bangka main island, Mindanao and Seliu island at Belitung. Information system webserver based on PHP and MySQL with focus to promote the specific information on each marine geosite for national and international network to make Marine Geopark will be known by all over the world. The next target is to gain for a UNESCO accreditation for the new developed Marine Geopark of Bangka Belitung specially and other small islands of Indonesia in general. The designated site for marine geopark then was protected legally with a community based village law.

\section{Acknowledgement}

The authors would like to thanks to Institute of Research and Development of Diponegoro University on Contract no. 474-81/ UN7.P4.3/PP/2018 and the Office of Planning and Development (BAPPEDA) of South Bangka Regency for the funding and also all staff of the both institutions, especially to Dr. Arief Febrianto.

\section{References}

1. Ministry of Internal Affairs (Depdagri) (2007) Verification and Toponimi of Bangka Belitung Islands (Verifikasi Penamaan Pulau di Kepulauan Bangka Belitung). Jakarta: Direktorat Jenderal Pemerintahan Umum.

2. Culture and Tourism Office of Bangka Belitung (Budpar Provinsi Kepulauan Bangka Belitung) (2010) Visit Bangka Belitung Archipelago 2010. Tourist Destination of Bangka Belitung. Pangkalpinang: Budpar Babel.

3. Hartoko A, Helmi M, Hariadi, Rukmi U, Wibowo A, et al. (2004) Supply of Thematic Spatial Data Sets of West Sumatera Coastal Zone. Research Report (Unpublish). Ministry of Fisheries and Marine Affairs and Asian Development Bank.

4. O'Brien JA, Marakas GM (2007) Management information systems. (10thedn) McGraw- Hill/Irwin, a business unit of The McGrawHill Companies.

5. Yogiyanto (2005) Strategic Information System. Andi Publishing, Yogyakarta.

6. Aaqib SM, Sharma L (2012) Analysis of Compute Vs Retrieve Intensive Web Applications and Its Impact on the Performance of a Web Server. International Journal Advanced Networking and Applications 3: 123339.

7. http://www.apache.org/

8. Mohamed B, Nordin NA (2007) Tourism Planning (Perancangan Pelancongan), Kuala Lumpur: Dewan Bahasa dan Pustaka. pp 33-34.

9. I GP, I KSD (2009) Introduction of Tourism. Andi Publishing, Yogyakarta.

10. Hakim L (2013) Website Super Wow PHP and Jquery Project. Yogyakarta, Lokomedia.

11. Kadir A (2006) Introduction of Information System (Pengenalan Sistem Informasi). Andi Publishing, Yogyakarta.

12. Utami E, Hartanto AD (2012) Database System Using Microsoft SQL Server 2005 (Sistem Basis Data menggunakan Microsoft SQL Server 2005) Andi Publishing, Yogyakarta.

13. Kim H, Richardson SL (2003) Impacts of a Popular Motion Picture on Destinations Perceptions. Annals of Tourisms Research. 30: 216-237.

14. Busby G, O’Neill K (2006) Cephallonia and Captain Corelli's Mandolin : the Influence of Literature and Film on British Visitors. Acta Turistica, 18: $30-51$.
15. Connell J (2005) Toddlers, Tourism and Tobermory : Destination Marketing Issues and Television Induced Tourism. Tourism Management. 26: 228-255.

16. http://www.executive.govt.nz/minister/clark/lor/lor.htm.

17. Tooke N, Baker M (1996) Seeing is believing: the effect of film on visitor numbers to screened locations. Tourism Management 17: 87-94.

18. Marry F, Somers H (2008) Bangka Tin and Muntok Pipper : The Role of Chinese Community in the Developement of Bangka Island XVIII - XX Century (Timah Bangka dan Lada Mentok: Peran Masyarakat Tionghoa dalam Pembangunan Pulau Bangka Abad XVIII - XX). Jakarta: Yayasan Nabil.

19. Verbeek (1897) The Geology of Indonesia. In: Bemmelen RW (editor). The Hague Martinus Nijhoff, IA.

20. Zwierzycki (1897) The Geology of Indonesia. In: Bemmelen RW (editor) The Hague, Martinus Nijhoff, IA.

21. Bemmelen RW (1970) The Geology of Indonesia. The Hague, Martinus Nijhoff: IA.

22. Barber AJ, Crow MJ, Milsom JS (2005) Sumatra : Geology, Resources and Tectonic Evolution. In: Cobbing EJ(editor) Geological Society Memoir, pp. 54-62.

23. Van Gorsel JT (2012) Sundaland : Bibliography of The Geology of Indonesia and Surrounding Areas. (4.1thedn) Bibliography of Indonesian Geology, Indonesia.

24. Mangga AS, Djamal B (1994) Geological Map of North Bangka (Peta Geologi Lembar Bangka Utara, Sumatra). Centre for Research and Development of Geology (Pusat Penelitian dan Pengembangan Geologi) Bandung.

25. Katili JA (1967) Structure and Age of The Indonesian Tin Belt With Special Reference to Bangka. Tectonophysics 4: 403-418.

26. Margono U, Supandjono RJB, Partoyo E (1995) Geology Map of South Bangka-Sumatera (Peta Geologi Lembar Bangka Selatan, Sumatra). Centre of Research and Development for Geology (Pusat Penelitian dan Pengembangan Geologi) Bandung.

27. Cobbing EJ, Mallick DIJ, Pitfield PEJ, Teoh LH (1986) The Granites of The Southeast Asian Tin Belt. J of Geological Society 143: 537-550.

28. Baharudin, Sidarto (1995) Geological Map of Belitung, Sumatra. Center for Geology Research and Development, Bandung.

29. Schwartz MO, Rajah SS, Askury AK, Putthapiban P, Djaswadi S (1995) The Southeast Asian Tin Belt. Earth-Sci Reviews 38: 95-293.

30. Crow MJ (2005) Pre-Tertiary Volcanic Rocks. In: Barber AJ, Crow MJ, Milsom JS (editors) Resources and Tectonic Evolution. Sumatra: Geology, Geological Society Memoir 31.

31. Yoeti OA (2008) Economic Tourist :Introduction Information and Implementation (Ekonomi Pariwisata: Introduksi, Informasi dan Implementasi, Jakarta: Penerbit Buku Kompas.

32. Noelle OC, Sheila F, David G (2008) The Integration of Film-induced Tourism and Destination Branding in Yorkshire . Int J Tourism Res 10: $423-37$.

33. Andrea H (2010) Lasykar Pelangi. In: Malay Language (editor) Selangor : PTS Litera Utama Sdn Bhd.

34. Eddy JAA (2001) Bangka in the Malay Imperium Trajectory (Bangka Dalam Lintasan Emperium Melayu). Seminar Internasional di PWTC Kuala Lumpur, Penyelenggara Gabungan Penulis Nasional Malaysia, Gappena.

35. Eddy JJA, Hamed MA, Tan WH (2010) The Influence Novel and Film Laskar Pelangi to the Tourism Industry at Belitong Island. Dipresentasikan dalam Seminar Internasional Hubungan MalaysiaIndonesia di Universiti Malaya, Kuala Lumpur. 